\title{
Papíralapú és számítógép-alapú tesztelés összehasonlító vizsgálata olvasás-szövegértés területén 4. évfolyamos diákok körében
}

A modern technika, a számitógépek elterjedése új lehetóségeket nyitott a tanulói teljesitmények értékelésében. Nemzetközi és hazai kutatások sora foglalkozott és foglalkozik ma is a kérdéssel, hogy

milyen hatással van a tanulók teljesítményére az IKT-eszközök használata a tesztelés folyamatában. A papíralapú tesztek átültetése számitógépes környezetbe annál is inkább ösztönzó lehet, mert a ma

diákja számára az IKT-eszközök a mindennapok használati tárgyaivá váltak (Tóth, 2015). Lényeges kutatási kérdés, hogy a számitógépes tesztelés befolyásolja-e a tanulók eredményeit. Nemzetközi és hazai vizsgálatok eltéró eredményre jutottak. Egyes kutatások nem találtak szignifikáns különbséget a hagyományos tesztek és a számitógépes környezetben elért teljesítmények között, mások éppen ellenkezóleg a közvetitó eszköz befolyásoló hatását állapitották meg (Csapó, Molnár, Pap-Szigeti és Tóth, 2009; Tóth és Hódi, 2011; Tóth, 2015).

A z utóbbi másfél évtizedben az oktatásban az egyik legerőteljesebben fejlődő terület a mérés-értékelés (Molnár, 2011). A tanórai folyamatoktól a köznevelés irányításáig mind több értékelhető információra van szükség az oktatás hatékonyabbá tételéhez. A rohamosan fejlődő információs-kommunikációs eszközök és technológiák kihasználása számtalan lehetőséget biztosít. Az oktatás folyamatának szinte minden fázisába jól integrálható, egyszerúbbé teszi a tesztelés folyamatát, gyorsítja az adatfelvételt, az adatelemzést (Csapó, Molnár, Pap-Szigeti és Tóth, 2009). Lehetővé teszi újszerü kérdezéstechnika alkalmazását, multimédia használatát, és adaptív tesztelési megoldásokat. Az IKT-eszközök és technológiák akkor hasznosulnak a leginkább, ha valós oktatási probléma megoldásában alkalmazzuk, nem pedig akkor, ha az információs-kommunikációs technika felhasználási lehetőségeit keressük (Csapó, Molnár, Pap-Szigeti és Tóth, 2009).

Új technológiai eszközök robbanásszerű megjelenése és elterjedése következtében gyermekeink ebbe a technológia-alapú világba születtek. Átszövik mindennapi életüket, így elkerülhetetlen a technológia iskolai alkalmazása. Gyorsan szeretnének információhoz jutni, az információhoz jutásuk során a szövegnél sokkal inkább előnyben részesítenek egyéb médiumokat. A mai diákok alapvetően másképp gondolkoznak, és másképp dolgozzák fel a környezetükből érkező információkat, mint 
elődeik. Digitális bennszülöttként életstílusuk, elvárásaik, tanulási felfogásuk módja hatást gyakorol az oktatással és a mérés-értékeléssel kapcsolatos elvárásaikra is (Prensky, 2001).

\section{Technológia-alapú mérések létjogosultsága}

Az utóbbi években elterjedő információ-kommunikációs technológiák, eszközök megjelenésével elkerülhetetlenné, nélkülözhetetlenné válik alkalmazásuk az oktatási folyamat során. Számos új lehetőséget kínálnak a tanulói teljesítmények értékelésére, a mérés korszerüsítésére (Pásztor-Kovács, Magyar, Hülber, Pásztor és Tongori, 2013). A tanulók eszközhasználati szokása, a vizsgálandó terület, a folyamat összes résztvevőjének IKT-kompetenciája mind hatással van az elektronikus tesztelés alkalmazására. Elterjedéséhez szükség van jól képzett tanárokra, akik az új módszereket alkalmazva tudják fejleszteni diákjaikat és integrálni a 21. században kulcsfontosságúnak számító képességek fejlesztését az iskolai oktató-nevelő munkába (Molnár, 2010).

Bevezetése mellett az egyik leggyakrabban említett érv a hosszú távú költséghatékonyság. Annak ellenére, hogy a technológia-alapú mérés rendszerének kiépítése viszonylag drága, de rendszeres használat mellett számos megtakarítás érhető el. Papíralapú tesztek nyomtatása, sokszorosítása, szállítása, javítása, kódolása, adatok rögzítése (Molnár, Magyar, Pásztor-Kovács és Hülber, 2015) nem jelentkezik költségként. Mindemellett a számítógép-alapú tesztek kiközvetítése nagyobb biztonsággal valósítható meg (Molnár, Magyar, Pásztor-Kovács és Hülber, 2015). A tesztelő rendszer automatikusan rögzíti a tanulók válaszait, és közvetítő eszköz használata nélkül kerülnek az adatok a rendszerbe. Az adatvesztés veszélye minimalizálható, illetve az adatrögzítés során alkalmazott emberi tényező (és ezáltal a rögzítés közbeni tévedés) kizárható. A feladattípusok nagyobb része azonnal javítható, lehetővé válik az azonnali kiértékelés és az eredmény gyors visszacsatolása (Csapó, Molnár és Tóth, 2008). Gazdaságosabbá, könnyebbé válik az adatok tárolása és visszakeresése is (Molnár, Magyar, Pásztor-Kovács és Hülber, 2015).

A számítógépes tesztek alkalmazásával javul mind az adatfelvételi, mind a kiértékelési objektivitás. Az adatfelvételi objektivitás akkor teljesül, ha a teszteredmények függetlenek az adatfelvevő személyétől (Csapó, 2000). Az automatikus adatrögzítéssel kiküszöbölhető a figyelmetlenségből származó hiba, illetve a javítás során a különféle megítélésből adódó eltérés (Molnár, Magyar, Pásztor-Kovács és Hülber, 2015).

A korábban papír-ceruza alapon vizsgált kompetenciákat gazdagabb vizuális és auditív ingereket tartalmazó feladatokkal mérhetjük (Tóth és Hódi, 2013). Olyan képességeket is tesztelhetünk, amelyekre papíralapon eddig nem volt lehetőségünk. Ilyen a dinamikus problémamegoldás, a digitális szövegértés vagy egyes számítógép-használathoz kötődő területek (e-mail rendezése, webes keresés stb.) vizsgálata (Tóth és Hódi, 2013). Megvalósítható vele az ún. adaptív tesztelés, amely a korábbi feladatokra adott válaszok helyességétől függően választja ki a feladatbankból a következő, megfelelő nehézségü feladatot a tanulónak. Helyes megoldás után egy nehezebb, helytelen válasz esetén egy könnyebb feladat következik (Molnár, 2013; Magyar és Molnár, 2013).

A számítógépes környezetnek köszönhetően a diákok szívesebben és nagyobb élvezettel oldják meg a számítógépes tesztet, mint a papír-ceruza változatot $(O E C D, 2010$, idézi Tóth és Hódi, 2013). A ma diákja sokkal jobban motiválható olyan ingergazdag tesztkörnyezet kialakításával, amelyhez hozzászokott: színes, dinamikus, sok képet, animációt tartalmaz (Molnár, Magyar, Pásztor-Kovács és Hülber, 2015). Mindazonáltal a számítógépes adatfelvételt önbevallás alapján nem kevésbé veszik komolyan a diákok, mint a nyomtatott változatot (OECD, 2010, idézi: Tóth és Hódi, 2013). 


\section{A számítógép-alapú mérés feltételei}

Ahhoz, hogy az oktatásban egyre nagyobb szerepet kapjon a technológia, és megvalósítható legyen az átállás a papíralapú tesztelésröl a számítógép-alapú tesztelésre, általánosan megfogalmazható kritérium a szükséges infrastruktúra biztosítása.

Az iskolák többségénél a számítógépek nem tekinthetők elavultnak, és egy osztálynyi tanulót le tudnak ültetni az IKT-teremben (Tóth, Molnár és Csapó, 2011). A megfelelő hardverellátottság mellett stabil hálózati kapcsolatra is szükség van, mert a számítógép-alapú tesztek jelentős része online módon valósul meg. Nem elég a kiszolgáló szerver részéről a gyors adatkiszolgálás, az internetkapcsolatnak is gyorsnak kell lennie. Az internetelérés gyakorlatilag 100 százalékos, de az internetkapcsolat típusa és sebessége nagyon változó (Molnár és Pásztor-Kovács, 2015).

Lényeges, hogy a tesztek ugyanúgy jelenjenek meg minden diák előtt, ezért nemcsak megfelelő paraméterekkel rendelkező monitort (monitorméret, képernyőfelbontás) kell alkalmazni (Molnár, Magyar, Pásztor-Kovács és Hülber, 2015), hanem kívánatos olyan böngészők használata, amelyeknél az információ megjelenésében nem tapasztalunk különbséget (Tóth, 2015).

A számítógép-alapú mérésre való áttérés bevezetésének további feltétele, hogy a pedagógusok megismerjék a 21. század innovatív mérési eszközeit, amelyek megfelelnek a nemzetközi elvárásoknak, és amelyek segítségével tanulóik értékelését rövidebb visszacsatolási idővel, objektíven el tudják végezni. A mérőeszközök megismerését követően fel kell öket készíteni, hogy az általuk kapott eredményeket megfelelöen értelmezzék. A kapott adatok a tanár segítségére kell legyenek abban, hogy célzottan tudjon beavatkozni az oktatási folyamatba. Mindezek nélkül nem nyer értelmet a mérés. Feladat tehát biztosítani az iskolák mérési-értékelési kultúrájának továbbfejlesztését, amely fokozatosan, a technológia-alapú mérés bevezetésével valósulhat meg (Molnár és Magyar, 2015).

Érdekes tény azonban, hogy a pedagógusok nagyobb mértékben nyitottak a változásokra, mint diákjaik (Molnár és Magyar, 2015). Egy vizsgálat megállapítása szerint növelhető a számítógép-alapú tesztelés elfogadottsága mind a pedagógusok, mind a diákok körében, ha használhatnák mindennapi munkájuk során, és a tanulók lehetőséget kapnának az elektronikus tesztek kipróbálására. Ha mód nyílna ennek biztosítására, akkor a bizalom növekedne, így az elutasítók száma jelentősen csökkenne (Molnár és Magyar, 2015).

\section{A médiahatás problematikája}

„A számítógép-alapú mérés-értékelési rendszerekre való áttérés akkor lehet felelősségteljes, ha ismerjük a médium megváltozásával járó teljesítménybefolyásoló hatásokat." (Pásztor-Kovács, Magyar, Hülber, Pásztor és Tongori, 2013. 87. o.) Nemzetközi ajánlások is szükségessé teszik a papír-ceruza alapú és a számítógépes teszteken elért eredmények összehasonlítását (International Guidelines on Computer-Based and Internet Delivered Testing - Bartram és Coyne, 2005; Standards for Educational and Psychological Testing - American Educational Research Association, American Psychological Association és National Council on Measurement in Education, 1999, idézi: Tóth, 2015).

Az 1990-es évek előtti összehasonlító mérések eredményeit tárgyaló tanulmányokban a vizsgálatok túlnyomó többségében igazolódott a médiahatás, és általában a papír-ceruza alapú teszteken értek el jobb eredményt a tesztelésben részt vevők. 1990 után folytatódtak a hagyományos és számítógép-alapú teszteken mutatott teljesítmények összehasonlító vizsgálatai. Ezek is eltérö képet mutatnak: egyes kutatások nem tártak fel szignifikáns különbséget (Tóth, 2015), mások igazolták a médiahatást, amely ismét a papíralapú teszteken elért eredményeknek ,kedvezett” (R. Tóth és Hódi, 2010). 
A tanulói teljesítmények mélyebb megértéséhez ismernünk kell a vizsgálatba bevont változók teszteredményre gyakorolt hatását. Van-e kapcsolat a nem, az életkor, a szülők iskolai végzettsége, a szocio-ökonómiai státusz és a médiahatás között? Mennyiben befolyásolják a számítógép-használati szokások, a számítógépes tapasztalat vagy attitüd az online tesztek eredményeit (Molnár, Magyar, Pásztor-Kovács és Hülber, 2015)?

\section{Médiahatás vizsgálata olvasás-szövegértés területén}

A nemzetközi kutatások leggyakrabban a matematika, a szövegértés, ritkábban az induktív gondolkodás területén hasonlítják össze a papír-ceruza és a számítógép-alapú mérés eredményeit. Az ezredforduló után a szövegértés képességterületen jelentős számú publikáció látott napvilágot különféle életkorú mintákat vizsgálva. Az eredmények különfélék. Egyes kutatások nem tapasztaltak médiahatást, mások igen. A szignifikánsan magasabb átlagot a vizsgálatok egy részénél a papíralapú teszt, másik részénél a számítógép-alapú mérés mutatta. A szöveg típusát illetően a folyamatos szövegek értésére fókuszáltak (Tóth és Hódi, 2011). A mintavételi eljárások közül a legjellemzőbb a véletlenszerü mintaalakítás és az egymintás adatfelvétel.

A szövegértés teszteknél feleletválasztó és feleletalkotó itemtípusokkal találkozhatunk. A feleletválasztó feladatok közül a többszörös választás dominál, míg a feleletalkotó feladatoknál a rövid és hosszú válasz, valamint az esszé egyaránt előfordul a tesztekben (Schnotz és Molnár, 2012). Kevés kutatás foglalkozott eddig az itemtípus és a médiahatás összefüggésével. Russell (1999), valamint Russell és Haney (1997, idézi: Tóth, 2015) munkája alapján a nyílt végü feladatoknál a számítógépes gyakorlottságból adódóan a tanulók hátrányba kerülhetnek online tesztek megoldásánál a papír-ceruza tesztet kitöltő diákokkal szemben.

\section{Célok, kutatási kérdések}

Jelen empirikus vizsgálat célja a médiahatás vizsgálata szövegértés területén, összehasonlítva a papír-ceruza és online környezetben felvett teszteken elért tanulói eredményeket, azaz megfigyelni a közvetítő eszköz hatását a tanulói teljesítményekre.

Kutatásomban választ keresek a következő kérdésekre:

- A hagyományos és a számítógép alapú teszteredmények különböznek-e egymástól, s amennyiben van eltérés, az szignifikáns-e? Valamint melyik tesztelési formában nyújtottak jobb teljesítményt?

- Szövegtípusonként van-e eltérés a papír-ceruza alapú és az online teszt eredményei között? Amennyiben mutatkozik eltérés, melyik változatban sikeresebbek a diákok?

- A különböző háttérváltozók hatással vannak-e a tanulói teljesítményre, és ha igen, azonosítható-e szignifikáns különbség? Mely változók magyarázzák leginkább az esetleges különbségeket?

\section{A kutatás módszerei}

\section{Minta és adatfelvétel}

A kutatás mintáját 4. évfolyamos diákok alkották $(\mathrm{N}=127)$, akik egy megyeszékhely második legnagyobb tanulólétszámú iskolájába járnak. A két feladatellátási helyen müködő öt párhuzamos osztály közül három a székhely intézményhez, kettő a tagin- 
tézményhez tartozik. A tanulók csaknem fele fiú. A minta kiválasztásánál nem volt cél a reprezentativitás. A hagyományos tesztet 127, a számítógép-alapú tesztet 126 tanuló oldotta meg. A kérdőívben feltett kérdésekre 122 fó válaszolt.

Az összehasonlító vizsgálat során azonos mintát alkalmaztam, azaz a vizsgálatban részt vevő tanulók megoldották mind a papíralapú, mind a számítógépes tesztet. Mindkét feladatellátási helyen osztálytermi környezetben az osztálytanító felügyeletével történt a hagyományos teszt feladatainak megoldása. Az objektivitás biztosítása érdekében a pedagógusok a kapott adatfelvételi útmutató alapján végezték a tesztfelvételt. Az egymást követő adatfelvételi eljárás hátránya, a gyakorlási és tanulási hatás ellensúlyozása érdekében a minta egyik része először a papír-ceruza alapú tesztet, a másik része az online tesztet oldotta meg.

A számítógépes teszt megoldása az iskolában elérhető internetkapcsolattal rendelkező számítógépeken zajlott. A tesztelés az eDia (Elektronikus diagnosztikus mérési rendszer) platform segítségével valósult meg (Molnár és Csapó, 2013; Molnár, Papp, Makay és Ancsin, 2015). Lebonyolítását megelőzően nem volt szükség programok telepítésére, csupán internetkapcsolatra és böngészőre. Általános böngésző elindítása után a tanulók mérési azonosítójukkal bejelentkeztek a tesztfelületre, majd megoldották a feladatokat. A rendszer nagyszerüsége folytán eredményükről azonnali visszajelzést kaptak százalékos formában.

A papíralapú és a számítógép-alapú teszt kitöltésére egyaránt 40 perc állt a tanulók rendelkezésére. A háttérkérdőív felvétele elektronikus formában, az online teszthez csatlakozóan történt, így biztosítva az egyszeri belépést. A papíralapú és az online teszt is lineáris volt, vagyis a feladatok meghatározott sorrendben követték egymást.

\section{A méröeszköz}

Saját készítésü 75 itemes olvasás-szövegértés teszttel történt a vizsgálat. A mérésnél használt teszteket a diákok papír-ceruza alapon és online környezetben is megoldották. Mind a papír-ceruza, mind a számítógépes teszt két részből áll. Az egyik formáját tekintve folyamatos, a másik nem folyamatos szöveg. A folyamatos szövegre épülő teszt 37 itemet, a nem folyamatos szöveget tartalmazó mérőeszköz 38 itemet tartalmazott.

A folyamatos szöveg 5 bekezdésre tagolt, 303 szót tartalmazó történelmi tárgyú leíró szövegfajta volt, amely 26 mondatból álló személyes célú olvasási szituációt teremtett. Az online változatban a folyamatos szöveg bekezdésekre tagolás nélkül jelent meg a monitoron, de egyéb paraméterei megegyeztek a papíralapú változattal. A második részteszt nem folyamatos tanulási célú szöveget tartalmazott, amelynél a tanulónak táblázatba rendezett információk között kellett eligazodnia.

Mindkét teszt papíralapú és számítógépes változatában a feladatok ugyanabban a sorrendben következtek egymás után, de megjelenésük szempontjából eltért a papír-ceruza alapú és az online teszt. A nyomtatott teszt esetében a tesztlap teljes terjedelmében volt látható. A szöveg egy oldalon, a feladatok további három oldalon követték egymást. A számítógép-alapú tesztnél a szöveg a monitor felső részén minden oldalon látható volt. A függőleges görgetősáv használatára a szöveg hossza miatt szükség volt. A feladatok a szöveg alatt egységes formátumban jelentek meg. A feladatutasítás és a válaszadó rész karaktereinek színe, mérete, betütípusa, a sorok távolsága minden feladatnál azonos volt (Pommerich, 2004, idézi Tóth és Hódi, 2011). A hagyományos teszt instrukcióinak megfogalmazása némileg eltért az online tesztben olvasottaktól a feladatmegoldás kivitelezése miatt (pl. papíralapú teszt esetében: „Karikázd be...” vagy „Húzd át...”; számítógépes tesztnél: „Kattintással jelöld...”). A diákok válaszaikat a jelölőnégyzetbe egérrel való kattintással adták meg, a következő feladatra a navigációs gombok használatával 
térhettek rá. Válaszaik módosítása érdekében lehetőségük volt visszalépni egy korábban már megoldott feladatra. A tesztek kizárólag zárt feladatokat tartalmaztak, mert szöveges válaszok megadásánál problematikus lehet a tanulók billentyüzet használatában való jártasságának befolyásoló szerepe.

A két résztesztből álló szövegértés teszt mellett a tanulók egy kérdöívet is kitöltöttek. Az adaptált kérdőív alapját egy 2010-ben felső tagozatos diákok körében végzett kutatásnál használt kérdéssor képezi, amely a papír-ceruza és a számítógép-alapú teszteredmények összehasonlítására irányult (Tóth, 2015). Az adaptáció szükséges volt, mert az eredeti kérdőív felső tagozatos tanulók számára készült, és jelen vizsgálatban negyedik osztályosok vettek részt, akiknek informatikai előtanulmányaik nincsenek. Ebben a tanévben tanultak elöször tanóra keretében informatikát, és életkoruknál fogva is jellemzően kevesebb számítógépes tapasztalattal rendelkeztek.

A kérdések egyik csoportja a háttéradatokat tárta fel (8 item), a másik a tanulók számítógép-használati szokásaira kérdezett rá (17 item). A háttéradatokból a diákok demográfiai jellemzőit ismerhettem meg (nem, szülök iskolai végzettsége, könyvek száma, IKT-eszközök megléte). A számítógépezési szokások feltárására irányuló tételek a számítógéphez kapcsolódó tapasztalataik és attitüdjeik iránt érdeklődtek. A kérdőív feleletválasztós kérdéseket tartalmazott. Benne dichotóm kérdőívtételek, 5-fokú gyakorisági skálán jellemezhető kérdések, valamint 5-fokú Likert-skálát $(1=$ egyáltalán nem igaz, 2 = nem igaz, 3 = igen is meg nem is, $4=$ igaz, 5 = nagyon igaz) alkalmazó állítások szerepeltek.

\section{Eljárások}

A tesztszintű elemzési módszerek elsősorban a papír-ceruza és számítógép-alapú teszteken mutatott teljesítményt hasonlítják össze. Az itemek vizsgálatakor klasszikus tesztelméleti módszerekkel elemeztem, melyek a nehéz és melyek a könnyebb itemek a kétféle tesztkörnyezetben. Vannak-e olyan itemek, amelyek hasonló nehézségúek a hagyományos és a számítógépes tesztek esetében? Az itemek nehézségének elemzésekor azt határozzuk meg, hogy a tanulók hány százaléka oldotta meg helyesen. Ha a kétféle tesztmédiumon az értékek hasonlóak, akkor azt az itemet médiahatás-függetlenként jellemezhetjük (Tóth, 2015). A tesztek és résztesztek megbízhatóságának vizsgálata során a Cronbach- $\alpha$ értékeket vettem alapul. Az érték ismeretében megállapítható, hogy azonos megbízhatósággal méri-e a papír-ceruza alapú és a számítógépes teszt a tanulók teljesítményét (Tóth, 2015).

\section{Eredmények}

\section{A tesztek megbízhatósága}

A papíralapon felvett szövegértés teszt reliabilitás-mutatója (Cronbach- $\alpha$ ) 0,87, míg a számítógépes tesztváltozaté 0,89 . A részteszteket külön vizsgálva is egymáshoz igen közeli értékeket kaptunk. A hagyományos tesztmédium Cronbach- $\alpha$ értéke folyamatos szöveg (37 item) esetén 0,79, nem folyamatos szövegnél (38 item) 0,83. A számítógépes tesztelésnél ezek a mutatók rendre 0,80 és 0,84 . Az adatok alapján megállapítható, hogy a mérőeszközök mindkét tesztmédiumon, és mind a teljes teszt, mind a résztesztek szintjén jól mérnek, annak ellenére, hogy a folyamatos szövegü teszt mutatója valamivel gyengébb a többinél. 


\section{Kétféle tesżtmédiumon mutatkozó eredmények}

A tanulók hagyományos és számítógép-alapú teszteredményei a különböző tesztmédiumokon a teljes teszt és a résztesztek szintjén is szignifikáns összefüggést mutatnak ( $\mathrm{r}_{\text {teljes }}$ teszt $\left.=0,58, \mathrm{p}<0,05 ; \mathrm{r}_{\text {folyamatos szọ̈veg }}=0,51, \mathrm{p}<0,05, \mathrm{r}_{\text {nem folyamatos szöveg }}=0,55, \mathrm{p}<0,05\right)$. A teljes teszt és a résztesztek pozitív korrelációja közepes.

A tanulók a hagyományos tesztelési folyamatban jobb eredményeket értek el, mint az online teszteknél. A különböző szövegtípusra épülő részteszteken elért átlagteljesítmények összehasonlításából kitünik, hogy az átlagok magasabbak a papíralapú tesztek esetében, de a szórások között alig van eltérés (ld. 1. táblázat). Ez arra enged következtetni, hogy a tanulók fejlettségbeli különbségei mindkét tesztmédiumon jelentkeztek, tehát a papíralapú teszt digitalizálásával csak az átlagos teljesítmény változott ( $R$. Tóth és Hódi, 2010). Mindkét tesztmédium esetében a diákok számára a nem folyamatos szöveg bizonyult könnyebbnek.

1. táblázat. Tanulók PP és CB tesztátlagai, azok szórásai és a t-próba eredményei szövegtípusonként

\begin{tabular}{|c|c|c|c|c|c|c|c|c|c|}
\hline \multirow{3}{*}{$\begin{array}{l}\text { Tesztmé- } \\
\text { dium }\end{array}$} & & & \multicolumn{3}{|c|}{ Szövegtipus } & & \multirow{2}{*}{\multicolumn{3}{|c|}{ Teljes teszt }} \\
\hline & \multicolumn{3}{|c|}{ Folyamatos } & \multicolumn{3}{|c|}{ Nem folyamatos } & & & \\
\hline & $\begin{array}{c}\text { Atlag } \\
(\%)\end{array}$ & $\begin{array}{c}\text { Szórás } \\
(\%)\end{array}$ & $t$ & $\begin{array}{c}\text { Atlag } \\
(\%)\end{array}$ & $\begin{array}{c}\text { Szórás } \\
(\%)\end{array}$ & $t$ & Átlag $(\%)$ & Szórás (\%) & $t$ \\
\hline PP & 74,97 & 14,02 & \multirow{2}{*}{2,56} & 76,67 & 15,20 & \multirow{2}{*}{2,93} & 75,83 & 12,64 & \multirow{2}{*}{3,31} \\
\hline $\mathrm{CB}$ & 71,97 & 13,14 & & 72,78 & 15,63 & & 72,38 & 12,90 & \\
\hline
\end{tabular}

Megjegyzés: PP: papiralapú, CB: számitógép-alapú

A t-próba eredményei alapján mind a teljes teszt, mind a résztesztek szintjén szignifikáns eltérés mutatkozik a tanulók papír-ceruza alapon és online változatban megoldott teszteredményei között [ $\mathrm{t}_{\text {_teljes teszt }}=3,31(\mathrm{p}<0,05) ; \mathrm{t}_{\text {_folyamatos szöveg }}=2,56(\mathrm{p}<0,05)$; $\mathrm{t}_{\text {_nem folya- }}$ matos szöveg $=2,93(\mathrm{p}<0,05)]$.

\section{Részmintákra irányuló elemzés}

Online tesztkörnyezetben nagyobb volt a fiúk és lányok átlagteljesítménye közötti különbség. Mind a fiúk, mind a lányok átlagosan magasabb eredményt értek el a papíralapú teszten, azaz a hagyományos tesztmédiumon könnyebben boldogultak a feladatmegoldással. A tesztek általánosságban nem bizonyultak nehéznek a diákok számára (ld. 1. ábra), ugyanakkor a legjobb és a legrosszabb eredmény között nagy a különbség. Az 1. ábrán apró karikák szemléltetik a szélső értékeket.

A papíralapon és online formában nyújtott teljesítményeket kétmintás t-próbával összehasonlítva megállapítható, hogy a fiúk és a lányok átlagai a teljes teszt szintjén nem különböztek egymástól. Résztesztek szintjén vizsgálódva a nem folyamatos szövegre épülő teszt online változatában a lányok szignifikánsan jobban teljesítettek ( $\mathrm{t}$ fiú-lány $=$ $-2,00, p=0,04)$. A két nemet külön-külön is vizsgáltam a papíralapú és az online teszteken elért eredmények tekintetében. A fiúk esetében a páros t-próba szignifikáns különbséget igazolt a teljes teszten és mindkét részteszten egyaránt. A lányok esetében a kétféle tesztmédiumon a teljes teszt és a résztesztek átlagaiban nem adódott szignifikáns különbség.

A papíralapú és számítógépes teszten mutatott teljesítmények korrelációja fiúk esetében $(\mathrm{r}=0,64, \mathrm{p}=0,00)$ erösebb a papíralapú és az online teszteredmények között, míg a lányoknál valamivel gyengébb $(\mathrm{r}=0,53, \mathrm{p}=0,00)$. 


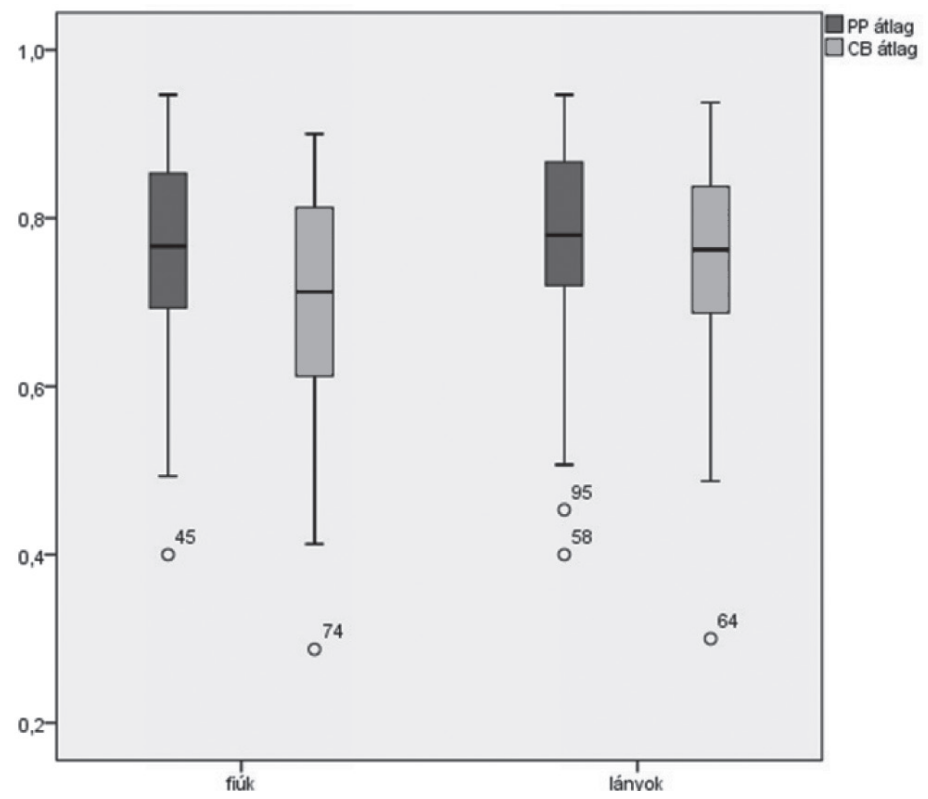

1. ábra. A fiúk és a lányok PP és CB teszteredményeinek box plot ábrája

\section{Háttérváltozók szerepe a médiahatás alakulásában}

Jelen kutatás kérdöíve az anya és apa iskolai végzettségén kívül a tanulók otthonában meglévő könyvek számára is rákérdezett. A szülők iskolázottsága és az otthoni könyvek száma közötti összefüggés-vizsgálat nem eredményezett kapcsolatot $\left(\mathrm{r}_{\text {anya }}=0,13\right.$, $\left.\mathrm{r}_{\text {ара }}=0,10, \mathrm{p}>0,05\right)$. A szülők iskolai végzettségének emelkedése nem feltétlenül eredményezett nagyobb otthoni könyvállományt. Az anya és az apa iskolázottsága egyaránt gyenge-közepes szinten korrelált a számítógépes tesztátlagokkal $\left(\mathrm{r}_{\mathrm{apa}}=0,34, \mathrm{r}_{\text {anya }}=0,31\right.$ $\mathrm{p}<0,01)$. A hagyományos tesztmédiumon felvett tesztek átlagai és az apa végzettsége között nem volt kapcsolat $(\mathrm{r}=0,15, \mathrm{p}=0,09)$, az anya iskolai végzettségével gyenge korrelációt mutattak $(\mathrm{r}=0,21, \mathrm{p}<0,05)$. Az anya iskolai végzettsége meghatározóbb szerepet játszott a teszteredmények alakulásában, mint az apáé.

A vizsgálatba bevont tanulók 96 százalékának van az otthonában számítógép (saját IKT-eszközök aránya 77 százalék), és internetkapcsolat is 93 százalékuknak rendelkezésére áll. Az otthoni számítógép vitathatatlan előnye a szabad hozzáférés, ami lehetővé teszi, hogy a tanuló saját maga kísérletezzen azzal, hogy miként tudja ezt az eszközt különféle céljaira felhasználni. Ám nem mindegy, hogy ezek mik. E célok vizsgálata érdekében kerültek a kérdöívbe azok a kérdések, amelyek az egyes számítógépes tevékenység gyakoriságát mérik fel a negyedik osztályos diákok között. Bizonyos célok eléréséhez ugyanis nagyon is sok kreativitás, erős motiváció és kitartás szükséges. Az erre vonatkozó eredményeket később ismertetem.

A tesztelésbe bevont negyedik osztályos tanulók IKT-tapasztalataikat csak iskolán kívüli forrásból szerezhették, hiszen ez az első tanévük, amikor informatikát tanultak. Más tanítási órán nem volt jellemző a számítógép egyéni vagy kiscsoportos használata. Kijelenthetjük, hogy az a diák, aki több időt tölt számítógépezéssel, nagyobb tapaszta- 
lattal rendelkezett. Az erre vonatkozó korrelációszámítás a minta egyes változói közötti összefüggés irányát és szorosságát mutatja. Az összefüggés szignifikáns $(r=0,67, p<0,01)$.

A számítógépes tapasztalat médiahatás-mértékre gyakorolt hatását vizsgáltam a következő változók segítségével: milyen gyakran számítógépezik, naponta mennyi időt tölt el előtte, és milyen gyakran internetezik. Lineáris regresszióval $(F=4,14, p<0,05)$ végzett számítások alapján csak a számítógép-használat gyakoriságára vonatkozó változónak van elenyésző $\left(R^{2}=0,033\right)$ magyarázó ereje.

Az IKT-eszközhasználat élvezetének, fontosságának és a számítógépes szorongásnak a médiahatás mértékére gyakorolt hatása a feltételezett eredményt hozta. Aki kedveli a számítógépet, az általában fontosnak is tartja, hogy jól megtanulja a használatát: a számítógép-használat fontossága és kedveltsége $(\mathrm{r}=0,44 \mathrm{p}<0,01)$. A számítógépezést kedvelők nem tartják nehéznek a kezelését $(\mathrm{r}=0,47 \mathrm{p}<0,01)$, nem gondolják, hogy unalmas $(\mathrm{r}=0,65$, $\mathrm{p}<0,01)$, és tanulnak is belőle $(\mathrm{r}=0,35, \mathrm{p}<0,01)$. Azok a tanulók, akik izgulnak számítógépezés közben, azok nem kedvelik $(\mathrm{r}=0,39, \mathrm{p}<0,01)$, nehéznek $(\mathrm{r}=0,63, \mathrm{p}<0,01)$ és unalmasnak $(\mathrm{r}=0,54, \mathrm{p}<0,01)$ találják. Nem gondolják úgy, hogy tanulhatnak a számítógép-használat során $(\mathrm{r}=0,18, \mathrm{p}<0,05)$. A számítógépes attitüdhöz tartozó egyes változók egyike sem mutatott összefüggést a médiahatás mértékével.

A kutatás mintáját alkotó tanulók iskolarendszerü informatikaoktatásban még nem vettek részt. Számítógépes ismereteiket valószínüleg a családban, a barátoktól vagy ismeretségi körükböl szerezték. Tevékenységeik többnyire az otthoni kikapcsolódáshoz kapcsolódóak voltak. A legnépszerübb tevékenységek a játék $(\bar{x}=3,25, \mathrm{Mo}=5)$ és a zenehallgatás $(\bar{x}=3,25, M o=5)$ volt. Átlaguk, móduszuk egyenlő, csak a medián értékében elözte meg a játék a zenét $\left(\mathrm{Me}_{\text {játék }}=4, \mathrm{Me}_{\text {zene }}=3\right)$. Legkevésbé a közösségi oldalakat látogatták, és amivel még ennél is ritkábban foglalkoztak, az a rajzolás ( $\bar{x}_{\text {közösségi oldal }}=2,48$, $\mathrm{Mo}=1, \bar{x}_{\text {rajz }}=2,43, \mathrm{Mo}_{1}=1$ ). A nemek számítógépes tevékenységeinek összehasonlításakor a fiúk nagyobb aktivitását tapasztaltuk. A korrelációanalízis eredményei alapján a számítógépes tevékenységek egyike sem volt összefüggésben a médiahatás mértékével.

\section{Médiahatás vizsgálata mintafelosztás segítségével}

A vizsgálatban részt vevő tanulókat a kvartilisek mentén három részmintára bontottam annak alapján, milyen eredményeket értek el a papír-ceruza teszten (Tóth és Hódi, 2011). A részminták alakulását a 2 . táblázat mutatja. Ha a tanulók átlaga valamelyik intervallum határára esett, akkor az összes ilyen tanuló ugyanabba a részmintába került. Ebből adódik, hogy az egyes részminták nem egyforma gyakoriságúak (Tóth és Hódi, 2011).

2. táblázat. A papír-ceruza alapú teszteredményeken alapuló mintafelosztás eredménye

\begin{tabular}{lcc}
\hline Részminták & Eredmények intervallumai & Gyakoriság (fö) \\
\hline 1. részminta & $0,00-0,73$ & 42 \\
\hline 2. részminta & $0,74-0,82$ & 38 \\
\hline 3. részminta & $0,83-1,00$ & 43 \\
\hline
\end{tabular}

A 2. ábrán pontfelhő segítségével jelenítettem meg a három részminta papír-ceruza és számítógépes tesztátlagait. A legoptimálisabb állapot az lenne, ha a tanulókat reprezentáló pontok a vastag piros vonalon vagy annak közelében lennének. Az 1. részminta a diagramterületen erösen szétszóródva jelenik meg. A háromszögek fele a vonal alatt, másik fele a vonal felett helyezkedik el. A 2., de különösen a 3. részmintánál figyelhetö meg, hogy azok a diákok, akik a hagyományos tesztmédiumon magas pontszámot értek el, online tesztkörnyezetben nem teljesítettek olyan jól. Ök jellemzően a piros vonal alatt helyezkednek el. 


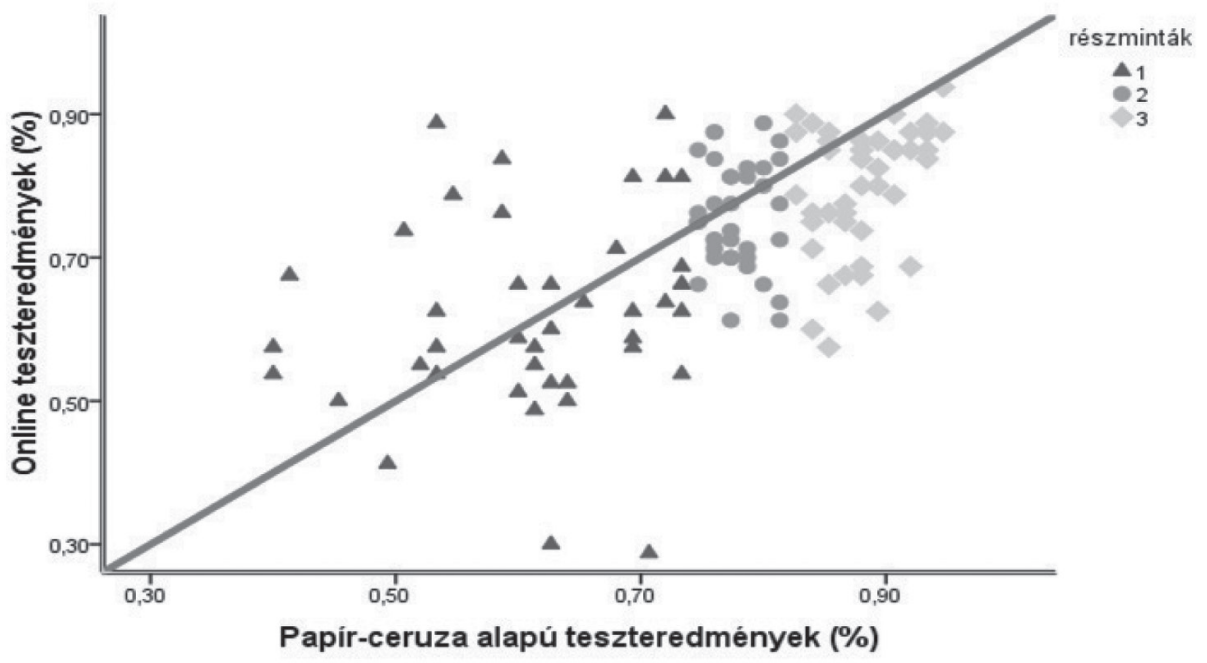

2. ábra. A részminták eredményei kétféle tesztmédiumon

Az egyes részminták médiahatás-mértékeinek összehasonlítására variancia-analízist alkalmaztam. A próbastatisztika $(\mathrm{F}=7,03 ; \mathrm{p}<0,05)$ és a Levene-próba szignifikáns eredménye $(9,59 ; \mathrm{p}=0,000)$ ismeretében a Dunnett T3 eljárás a következő eredményt adta. Az 1. és a 2. csoport átlagai között nem, viszont a 2. és 3., illetve az 1. és 3. csoport teljesítményei között szignifikáns különbség adódott $(\mathrm{p}<0,05)$.

\section{Tesztek itemjellemzöi}

A tesztelemzés során a mérőeszközök itemszintü vizsgálatának feltétele, hogy a papír-ceruza és a számítógépes alapú tesztek ugyanazokat az itemeket tartalmazzák (Tóth, 2015). Az itemszintü elemzés során megtudhatjuk, melyek azok az itemek, amelyek a kétféle tesztmédiumon eltérően müködnek, eltérő nehézségüek. Az itemjellemzők feltárásával azonosíthatók azok az itemek, amelyek a médiahatás okozói lehetnek. Az itemnehézség a helyes megoldások számának és az összes megoldások számának hányadosa. A kapott érték 0 és 1 közötti szám, amely minél közelebb van az 1-hez, annál könnyebb az item.

A 3. ábra a teljes teszt szintjén a két tesztmédium itemnehézségi mutatóit szemlélteti. A kör a papír-ceruza alapú, a háromszög a számítógépes teszt itemnehézségi mutatóit reprezentálja. Azoknál az itemeknél, amelyeknél a jelölők egymást takarják, vagy nagyon közel vannak egymáshoz, ott az itemek médiahatás-függetlenek (Tóth, 2015). Ahol egymástól távolabb helyezkednek el, ott az itemnehézség mutatója eltér a kétféle tesztmédiumon. Ezek az eltérően müködő itemek (Tóth, 2015). A 3. ábrán látható, hogy a papír-ceruza és a számítógépes tesztek itemnehézségei között az itemek számottevő részénél jelentős különbség nem adódik. 


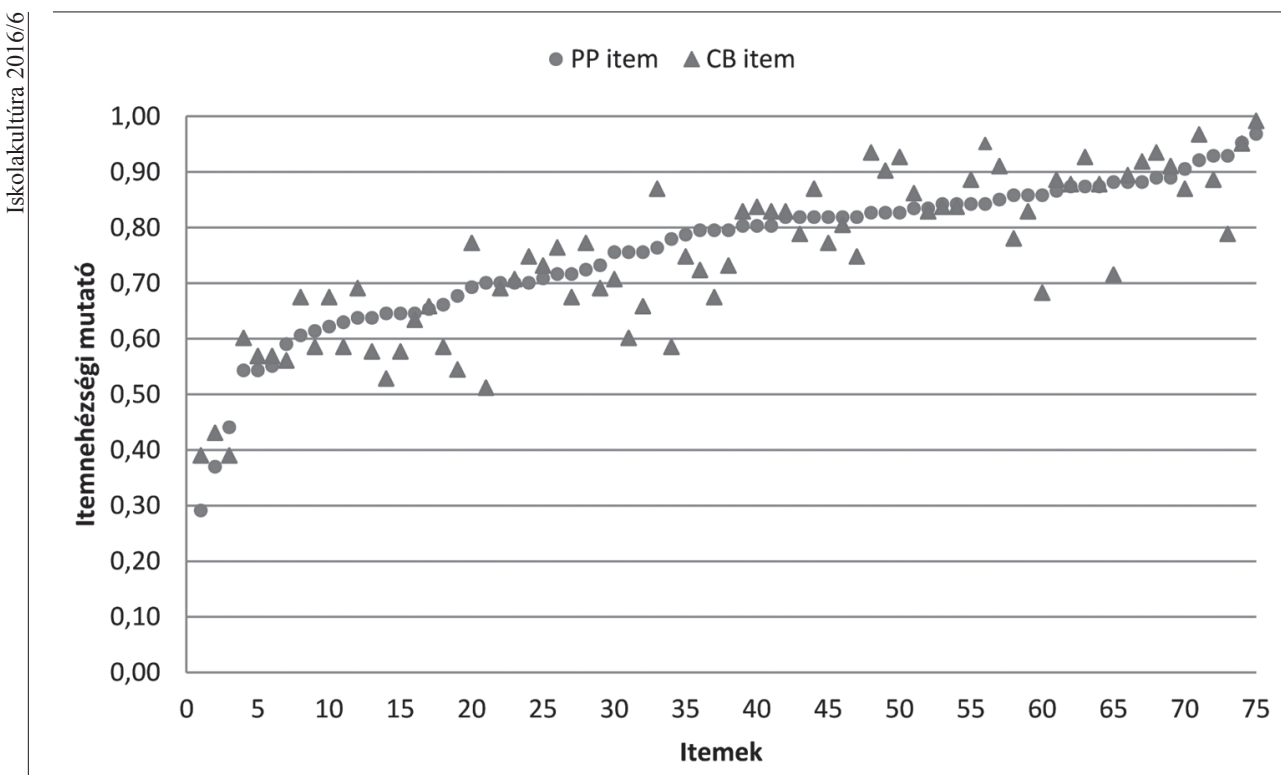

3. ábra. A papír-ceruza és online környezetben felvett teljes tesztek itemnehézségi mutatói a papíralapú itemek nehézsége szerinti sorba rendezve

A résztesztek szintjén történt itemnehézség-vizsgálat eredményeit a 4. ábra mutatja. A sorba rendezett értékeket a nyomtatott és a számítógépes tesztek itemnehézségi mutatóinak különbsége adja. Az itemek néhány kivételtöl eltekintve a nem folyamatos teszten könnyebbek voltak. Egy korábban tett megállapítás megerősítést nyert, miszerint a tanulók a nem folyamatos szöveggel készült teszten jobb eredményt értek el.

A papír-ceruza alapon és online formában kiközvetített teszt átlagos itemnehézségi mutatóit számoltam ki, és t-próbával megvizsgáltam, van-e az átlagok között szignifikáns különbség. A számítások eredményeit a 3. táblázat tartalmazza. A próba eredménye mind a teljes teszt, mind a résztesztek szintjén szórásegyezést mutatott, és a próbastatisztika az átlagok egyezését adta. Tehát a papír-ceruza és a számítógép-alapú tesztek itemjeinek müködése között nincs jelentős eltérés, ezáltal médiahatás sem igazolódik.

3. táblázat. A kétféle tesztmédiumon végzett t-próba statisztikája

\begin{tabular}{|l|c|c|c|c|c|c|}
\hline \multirow{2}{*}{} & \multicolumn{2}{|c|}{$P P$} & \multicolumn{2}{c|}{ CB } & \multirow{2}{*}{$t$} & \\
\cline { 2 - 6 } & $\begin{array}{c}\text { Átlag } \\
(\%)\end{array}$ & $\begin{array}{c}\text { Szórás } \\
(\%)\end{array}$ & $\begin{array}{c}\text { Átlag } \\
(\%)\end{array}$ & $\begin{array}{c}\text { Szórás } \\
(\%)\end{array}$ & & \\
\hline Teljes teszt & 0,758 & 0,13 & 0,748 & 0,15 & 0,48 & n.s. \\
\hline $\begin{array}{l}\text { Részteszt 1. } \\
\text { (Folyamatos szöveg) }\end{array}$ & 0,750 & 0,14 & 0,752 & 0,15 & $-0,05$ & \multirow{2}{*}{ n.s. } \\
\hline $\begin{array}{l}\text { Részteszt 2. } \\
\text { (Nem folyamatos szöveg) }\end{array}$ & 0,766 & 0,12 & 0,743 & 0,14 & 0,79 & n.s. \\
\hline
\end{tabular}

A kétféle szövegtípus itemnehézségi mutatóit t-próbával összevetve szórásegyezést figyelhetünk meg $(\mathrm{F}=1,20 ; \mathrm{p}>0,05)$, és a próbafüggvény értékéből arra következtethetünk, hogy a 2 . részteszt volt a könnyebb $(\mathrm{t}=-0,19 ; \mathrm{p}>0,05)$, de nem szignifikánsan. A folyamatos és nem folyamatos szöveg értését mérő tesztek itemnehézségi 


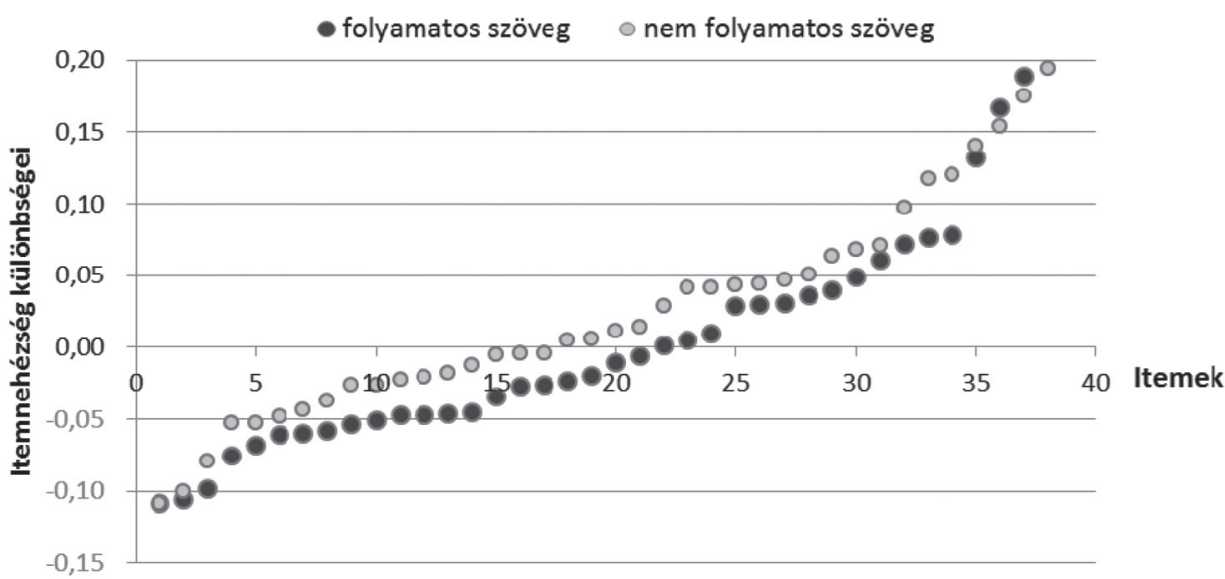

4. ábra. Papír-ceruza és online itemnehézségi mutatók különbségei nagyság szerint sorba rendezve szövegtípus szerinti bontásban

mutatói között sem adódott szignifikáns különbség. A t-próba negatív előjele arra enged következtetni, hogy itemszinten is a nem folyamatos szöveg bizonyult valamivel könnyebbnek.

\section{Összegzés}

Negyedik évfolyamos tanulók médiafüggő viselkedését vizsgáltam saját folyamatos és nem folyamatos szövegeket tartalmazó teszteken. Elemzésem egy része igazolta a korábbi kutatások konklúzióit, mások pedig azoktól eltérö eredményt hoztak. Az eddigi vizsgálatokhoz hasonlóan a mintámat alkotó diákok nemtől függetlenül mind a teljes teszt, mind a résztesztek szintjén a papíralapú változaton teljesítettek jobban. A kétféle tesztmédiumon kapott eredmények pozitív, közepes mértékü korrelációt mutattak egymással. Az általam végzett vizsgálatok a korábbiakkal ellentétben nem igazoltak nagyobb mértékü médiahatást a folyamatos szövegü tesztek esetében. Hipotézisemet, mely szerint sem a fiúk, sem a lányok teljesítménye nem különbözik számítógép-alapon felvett teljes teszt és az egyik részteszt szintjén sem, nem tudtam igazolni. A nem folyamatos szövegü teszten a lányok szignifikánsan jobb eredményt értek el. A háttérváltozók tekintetében is vegyes a kép. A médiahatást, ha gyengén is, de befolyásolja a számítógépes tapasztalat, de az attitüd nem. A tesztek itemszintű vizsgálatakor adódott olyan item, amely az online teszten bizonyult könnyebbnek, így maradéktalanul nem igazolódott az a korábbi feltételezés, miszerint minden itemet papíralapon eredményesebben oldottak meg a diákok. Vizsgálatom további kérdéseket vet fel: Mi okozhatja az egyes itemek eltérö múködését? Mivel magyarázható az, hogy bizonyos itemek a hagyományos tesztkörnyezetben voltak könnyebbek, mások pedig online környezetben?

Személy-item térkép felrajzolása hasznos lehet a teszt fejlesztése szempontjából, mert megmutatná, milyen nehézségü itemek hiányoznak a tesztből. További információkat kaphatnánk a tanulók képességszintjeiről is. A sétálóutca analógiáját felhasználva megtudhatnánk belöle, volt-e olyan diák, aki csalt a tesztkitöltés közben (a társáról másolta a feladatmegoldásokat) (Molnár, 2006). 
Az eddigi vizsgálatokhoz hasonlóan a mintámat alkotó diákok nemtól függetlenül mind a teljes teszt, mind a résztesztek szintjén a papíralapú változaton teljesitettek jobban. A kétféle tesztmédiumon kapott eredmények pozitív, közepes mértékú korrelációt mutattak egymással. Az általam végzett vizsgálatok a korábbiakkal ellentétben nem igazoltak nagyobb mértékú médiahatást a folyamatos szövegú tesztek esetében. Hipotézisemet, mely szerint sem a fiúk, sem a lányok teljesitménye nem különbözik számitógép-alapon felvett teljes teszt és az egyik részteszt szintjén sem, nem tudtam igazolni.
Az eDia rendszer kontextuális adatok rögzítésére is képes. Mérhetővé válik, hogy egy diák mennyi időt töltött egy feladattal, és a feladatmegoldás során milyen válaszokat jelölt meg, amíg a véglegeset ki nem választotta. Rögzítésre kerül az is, hogy mely feladatra tért vissza akár többször is (Molnár, Papp, Makay és Ancsin, 2015; Tóth és Hódi, 2013). Vizsgálati eredményeinket árnyalná, ha kiegészítenénk adatainkat azzal, hogy egy-egy item megoldásával mennyi idő töltött egy tanuló. Feltehetnénk egy újabb kérdést: Az itemnehézség és az item megoldási ideje között van-e szignifikáns kapcsolat? A kapott adatok elemzése során kiszürhetjük azokat a tanulókat, akik nem gondolkodtak, hanem csak továbbkattintottak (Molnár, Magyar, Pásztor-Kovács és Hülber, 2015). Az elemzést kiegészítve következtethetnénk arra, hogy a tanulók mennyire komolyan veszik az online tesztek megoldását.

\section{Irodalomjegyzék}

Csapó Benő (2000): Tudásszintmérő tesztek. In: Falus Iván (szerk.): A pedagógiai kutatás módszerei. Müszaki Könyvkiadó, Budapest. 277-316.

Csapó Benő, Molnár Gyöngyvér és R. Tóth Krisztina (2008): A papír alapú tesztektől a számítógépes adaptív tesztelésig: a pedagógiai mérés-értékelés technikájának fejlődési tendenciái. Iskolakultúra, 18. 3-4. sz. 3-16.

Csapó Benő, Molnár Gyöngyvér, Pap-Szigeti Róbert és R. Tóth Krisztina (2009): A mérés-értékelés új tendenciái: a papír- és számítógép-alapú tesztelés összehasonlító vizsgálatai általános iskolás, illetve föiskolás diákok körében. In: Perjés István és Kozma Tamás (szerk.): Új kutatások a neveléstudományokban. Hatékony tudomány, pedagógiai kultúra, sikeres iskola. Magyar Tudományos Akadémia, Budapest. 99-108.

Magyar Andrea és Molnár Gyöngyvér (2013): Adaptív és rögzített formátumú tesztek alkalmazásának összehasonlító hatékonyságvizsgálata. Magyar Pedagógia, 113. 3. sz. 181-193.
Molnár Gyöngyvér (2006): A Rasch-modell alkalmazása a társadalomtudományi kutatásokban. Iskolakultúra, 16. 12. sz. 99-113.

Molnár Gyöngyvér (2010): Technológia-alapú mérésértékelés hazai és nemzetközi implementációi. Iskolakultúra, 20. 7-8. sz. 22-34.

Molnár Gyöngyvér (2011): Az információs-kommunikációs technológiák hatása a tanulásra és oktatásra. Magyar Tudomány, 171. 9. sz. 1038-1047.

Molnár Gyöngyvér (2013): A Rasch modell alkalmazási lehetöségei az empirikus kutatások gyakorlatában. Gondolat Kiadó, Budapest.

Molnár Gyöngyvér és Csapó Benő (2013): Az eDia online diagnosztikus mérési rendszer. Előadás. XI. Pedagógiai Értékelési Konferencia, Szeged, 2012. április $11-13$.

Molnár Gyöngyvér és Magyar Andrea (2015): A számítógép-alapú tesztelés elfogadottsága pedagógusok és diákok körében. Magyar Pedagógia, 115. 1. sz. 49-66. DOI: 10.17670/mped.2015.1.47 
Molnár Gyöngyvér és Pásztor-Kovács Anita (2015): A számítógépes vizsgáztatás infrastrukturális kérdései: az iskolák eszközparkjának helyzete és a változás tendenciái. Iskolakultúra, 25. 4. sz. 49-61. DOI: 10.17543/iskkult.2015.4.49

Molnár Gyöngyvér, Magyar Andrea, Pásztor-Kovács Anita, és Hülber László (2015): A mérési-értékelési rendszer elektronikus alapokra helyezésével kapcsolatos helyzetelemzés. 2016. 02. 01-i megtekintés, http://www.oktatas.hu/pub_bin/dload/unios_projektek/tamop318/OKM_kutatasi_eredmenyek2015/ meresi_ertekelesi_rendszer.pdf

Molnár Gyöngyvér, Papp Zoltán, Makay Géza és Ancsin Gábor (2015): eDia 2.3 Online mérési platform - feladatfelviteli kézikönyv. SZTE Oktatáselméleti Kutatócsoport, Szeged.

OECD (2010): PISA Computer-Based Assessment of Student Skills in Science. OECD Publishing, Paris. DOI: $10.1787 / 9789264082038$-en

Pásztor-Kovács Anita, Magyar Andrea, Hülber László, Pásztor Attila és Tongori Ágota (2013): Áttérés online tesztelésre - a mérés-értékelés új dimenziói. Iskolakultúra, 11. sz. 86-100.

Prensky, M. (2001): Digitális bennszülöttek, digitális bevándorlók. On the Horizon, 9. 5. sz. 2016. 02. 01-i megtekintés http:/goliat.eik.bme.hu/ emese/gtk-o/ didaktika/digital_kids.pdf

R. Tóth Krisztina és Hódi Ágnes (2010): Olvasási képesség mérése számítógépes környezetben. In:
Kozma Tamás és Perjés István (szerk.): Új kutatások a neveléstudományokban 2009. Aula Kiadó, Budapest. 145-157.

Schnotz, W. és Molnár Edit Katalin (2012): Az olvasás-szövegértés mérésének társadalmi és kulturális aspektusai. In: Csapó Benő és Csépe Valéria (szerk.): Tartalmi keretek az olvasás diagnosztikus értékeléséhez. Nemzeti Tankönyvkiadó, Budapest. 87-136.

Tóth Edit, Molnár Gyöngyvér és Csapó Benő (2011): Az iskolák IKT-felszereltsége - helyzetkép országos reprezentatív minta alapján. Iskolakultúra, 21. 10-11. sz. 124-137.

Tóth Krisztina (2015): Felső tagozatos diákok papirceruza és számítógép-alapú teszteredményeinek összehasonlitó vizsgálata szövegértés, induktív gondolkodás és problémamegoldás terén. $\mathrm{PhD}$-értekezés, Szegedi Tudományegyetem, Szeged. DOI: 10.14232/ phd. 2785

Tóth Krisztina és Hódi Ágnes (2011): Számítógépes és papír-ceruza teszteredmények összehasonlító vizsgálata az olvasás-szövegértés területén. Magyar Pedagógia, 111. 4. sz. 313-332.

Tóth Krisztina és Hódi Ágnes (2013): A mérőeszközbővítéstől a tesztelési folyamat vizsgálatáig: számítógépes tesztelés nagymintás nemzetközi vizsgálatokban. Iskolakultúra, 22. 9. sz. 75-88. 